\title{
Pendampingan Penyusunan Rancangan Qanun Pengelolaan Satwa Liar di Aceh
}

\author{
Rachmatika Lestari ${ }^{1}$, Eza Aulia ${ }^{2}$, Phoenna Ath-Thariq ${ }^{3}$, Asmaul Husna ${ }^{4}$ \\ 1,2,3 Prodi Ilmu Hukum, Universitas Teuku Umar \\ Email: rachmatikalestari@utu.ac.id \\ Email: ezaaulia@utu.ac.id \\ Email: phoennaaththariq@utu.ac.id \\ 4Prodi Ilmu Komunikasi, Universitas Teuku Umar \\ Email: asmaulhusna@utu.ac.id
}

Submitted: 25 Juni 2020 Revised: 27 Juni $2020 \quad$ Accepted: 04 Juli 2020

\begin{abstract}
Human conflict with wildlife is a complex problem because it isn't only related to human safety but also with the safety of wildlife itself. Conflicts that have occurred have pushed the Government of Aceh, District/City Government and related parties to be more wise in understanding the lives of wild animals so that the handling and prevention measures can be optimized and based on the root of the problem. For this reason, a legal protection is needed in the form of a qanun which is expected to be able to integrate all available resources to protect wildlife in Aceh. The method of implementation in community service is to get involved with the expert team Commission II DPRA in drafting the Qanun of Wildlife Management until finally the qanun was ratified on 27 September 2019 and then promulgated to be Qanun on 29 October 2019. The participation of the authors in the drafting of the draft qanun of wildlife includes part of the process of forming the qanun, including starting from the stages of planning, drafting, and discussion. While the stages of ratification or stipulation, enactment and dissemination are carried out by the DPRA and the Government of Aceh itself in accordance with their respective duties, functions and authorities.
\end{abstract}

Keywords: Draft Qanun, Wild Animal, Aceh

\begin{abstract}
Abstrak
Konflik manusia dengan satwa liar merupakan permasalahan yang kompleks karena bukan hanya berhubungan dengan keselamatan manusia tetapi juga dengan keselamatan satwa liar itu sendiri. Berbagai konflik yang terjadi telah mendorong Pemerintah Aceh, Pemerintah Kabupaten/Kota dan para pihak terkait untuk lebih bijaksana dalam memahami kehidupan satwa liar sehingga tindakan penanganan dan pencegahannya dapat lebih optimal dan berdasarkan akar permasalahannya. Untuk itu, diperlukan sebuah payung hukum dalam bentuk qanun yang diharapkan mampu mengintegrasikan semua sumber daya yang dimiliki guna melakukan perlindungan terhadap satwa liar di Aceh. Metode pelaksanaan dalam pengabdian kepada masyarakat ini adalah dengan turut terlibat bersama tim tenaga ahli komisi II DPRA dalam menyusun draft Qanun Pengelolaan Satwa Liar hingga akhirnya qanun ini disahkan pada 27 September 2019 dan kemudian diundangkan menjadi Qanun pada 29 Oktober 2019 lalu. Turut sertanya penulis dalam penyusunan draft qanun satwa liar ini adalah meliputi sebagian dari proses tahapan pembentukan qanun, antara lain mulai dari tahapan perencanaan, penyusunan, dan pembahasan. Sedangkan tahapan pengesahan atau penetapan, pengundangan, dan penyebarluasan dilakukan oleh DPRA dan Pemerintah Aceh sendiri sesuai dengan tugas, fungsi dan wewenangnya masing-masing.
\end{abstract}

Kata Kunci: Rancangan Qanun, Satwa Liar, Aceh 


\section{PENDAHULUAN}

Sebagaimana yang tertuang dalam Pasal 1 ayat (3) pembukaan Undang-Undang Dasar 1945 yang menyatakan "Negara Indonesia adalah negara hukum". Oleh karena itu pada dasarnya segala tingkah laku manusia haruslah diatur berdasarkan adanya hukum yang bekerja dengan cara memberikan petunjuk tentang tingkah laku setiap manusia. Hukum yang dimaksud merupakan perwujudan dari norma yang hidup dan berkembang di dalam masyarakat (Soekanto, 2007).

Indonesia merupakan salah satu negara yang kaya akan sumber daya alam, baik hayati maupun nonhayati. Sumber daya hayati Indonesia dikenal tidak saja kaya tetapi juga mempunyai keunikan tertentu di setiap daerah. Sumber daya alam tersebut mempunyai kedudukan serta peranan penting bagi kehidupan dan merupakan karunia Tuhan Yang Maha Esa. Oleh karena itu perlu dikelola dan dimanfaatkan secara lestari, selaras, serasi dan seimbang bagi kesejahteraan masyarakat Indonesia pada khususnya dan umat manusia pada umumnya, baik masa kini maupun masa depan. Bumi, air, dan kekayaan alam yang terkandung di dalamnya, merupakan sebuah anugerah dari Tuhan Yang Maha Esa yang diperuntukkan bagi bangsa Indonesia yang tidak dapat terhitung jumlahnya.

Satwa liar juga merupakan ciptaan dari pencipta alam semesta yang harus dijaga keberlanjutannya dan dilindungi dari kepunahan. Aceh beserta dengan bentang alam dan ekosistemnya merupakan tempat hidup bagi satwa liar yang kompleks termasuk satwa liar spesies kunci terancam punah yaitu gajah, harimau, orangutan, badak, penyu, tuntong, dan dugong yang jumlahnya terus berkurang sehingga diperlukan adanya upaya perlindungan. Upaya perlindungan satwa liar bukan hanya tanggung jawab pemerintah, tapi juga menjadi tanggung jawab masyarakat sehingga pelibatan masyarakat mutlak diperlukan.

Berdasarkan ketentuan Pasal 1 angka 10 Undang-Undang Nomor 32 Tahun 2004 sebagaimana yang telah diubah dengan UndangUndang Nomor 23 Tahun 2014 dan dilakukan perubahan kembali dengan Undang-Undang Nomor 9 Tahun 2015 tentang Pemerintahan Daerah, yang dimaksud dengan Peraturan daerah adalah Peraturan Daerah Provinsi dan/atau peraturan daerah Kabupaten/kota. Peraturan daerah dibuat oleh pemerintah daerah dalam rangka untuk menjalankan otonomi daerah dalam negara kesatuan Republik Indonesia. Peraturan Daerah adalah 
semua peraturan yang dibuat oleh pemerintah setempat untuk melaksanakan peraturan-peraturan lain yang lebih tinggi derajatnya (Bagir Manan, 2002:136). Di Aceh, Peraturan Daerah ini disebut dengan Qanun.

Secara nasional, perlindungan terhadap satwa liar diatur dalam Undang-Undang Nomor 5 Tahun 1990 tentang Konservasi Sumber Daya Alam Hayati dan Ekosistemnya. Oleh sebab itu untuk melaksanakan peraturan yang lebih tinggi derajatnya tersebut, perlu adanya peraturan daerah yang mengatur mengenai perlindungan terhadap satwa liar.

Akhir-akhir ini termasuk di Aceh, konflik antara manusia dan satwa liar cenderung meningkat. Pada kondisi tertentu konflik tersebut dapat merugikan semua pihak yang berkonflik. Kerugian yang umum terjadi akibat konflik di antaranya seperti rusaknya tanaman pertanian dan/atau perkebunan serta pemangsaan ternak oleh satwa liar, atau bahkan menimbulkan korban jiwa manusia. Bahkan, tidak jarang satwa liar yang berkonflik mengalami kematian akibat berbagai tindakan penanggulangan konflik yang dilakukan (Redaksi, 2019).

Tim ranger dari Forum Konservasi Lauser (FKL) selama 4 tahun terakhir berhasil memusnahkan 5.529 jerat yang banyak melukai dan membunuh satwa di kawasan hutan di Aceh seperti yang terjadi pada satu dari dua ekor beruang madu (Helarctos malayanus) yang terkena jerat babi di pegunungan Desa Ladang Neubok, Kecamatan Jeumpa, Aceh Barat Daya, Aceh. Hasil investigasi gabungan FKL dan Yayasan Hutan Alam dan Lingkungan Aceh (HAKA) mencatat sepanjang tahun 2018 lalu ada sekitar 380 kasus perburuan satwa liar dengan lokasi perburuan terbanyak terjadi di Kabupaten Aceh Selatan, Kota Subulussalam dan Kabupaten Aceh Barat Daya (ABC, 2019).

Satwa liar yang sering berkonflik dengan manusia antara lain gajah, harimau, orangutan, dan badak. Sedangkan satwa liar yang menjadi sasaran para pemburu adalah yang mempunyai nilai jual yaitu gajah, trenggiling, harimau, gajah dan lainnya. Seperti yang terjadi di kawasan hutan Leuser Aceh, akibat dari pemasangan jerat yang banyak membunuh dan melukai satwa liar, kaki kiri anak gajah sumatera berumur satu tahun nyaris putus akibar jerat yang dipasang pemburu di hutan Kecamatan Simpang Jernih, Kabupaten Aceh Timur, Aceh, pada 18 Juni 2019. (vivanews.com:2019).

Konflik manusia dengan satwa liar merupakan permasalahan yang 
kompleks karena bukan hanya berhubungan dengan keselamatan manusia tetapi juga dengan keselamatan satwa liar itu sendiri. Berbagai konflik yang terjadi telah mendorong Pemerintah Aceh, Pemerintah Kabupaten/Kota dan para pihak terkait untuk lebih bijaksana dalam memahami kehidupan satwa liar sehingga tindakan penanganan dan pencegahannya dapat lebih optimal dan berdasarkan akar permasalahannya.

Banyak upaya yang telah dilakukan oleh berbagai pihak seperti perbaikan habitat alami satwa liar, meminimalisir dan merehabilitasi kerusakan hutan, serta mengontrol pemanfaatan berlebihan jenis flora dan fauna. Namun, upaya-upaya tersebut belum berhasil mengatasi akar persoalan yang sesungguhnya. Untuk itu, diperlukan sebuah payung hukum dalam bentuk qanun yang diharapkan mampu mengintegrasikan semua sumber daya yang dimiliki guna melakukan perlindungan terhadap satwa liar di Aceh (Nurzahri, Ketua Komisi 2 DPRA:2019).

Qanun ini memuat norma hukum lingkungan hidup. Normanorma itu dituangkan dalam bentuk pengaturan mengenai tujuan dan sasaran perlindungan satwa liar, perlindungan satwa liar terpadu, kelembagaan dan koordinasi, koridor satwa liar, peran serta masyarakat, rehabilitasi dan relokasi satwa liar, serta larangan-larangan yang harus dipatuhi oleh semua pihak agar dapat menjamin kelestarian dan keberlanjutan satwa liar di bumi Aceh. Qanun ini diharapkan menjadi landasan hukum bagi Pemerintah Aceh, Pemerintah kabupaten/kota dan pemangku kepentingan lainnya dalam melakukan perlindungan satwa liar di Aceh.

Rancangan Qanun tentang Pengelolaan Satwa Liar sebelumnya diinisiasi dengan nama Rancangan Qanun Perlindungan Satwa Liar. Proses rancangan qanun ini sudah berlangsung sejak Tahun 2017. Awalnya ada desakan dari rekanrekan

Non-Governmental Organization (NGO) yang bergerak di isu lingkungan terkait konflik satwa di Aceh, hal ini karena banyaknya satwa liar yang mati dan masyarakat yang menjadi korban, bahkah ada masyarakat yang meninggal akibat konflik dengan satwa liar. Atas desakan dari beberapa pihak tersebut, Komisi II Dewan Perwakilan Rakyat Aceh (DPRA) pada 2017 menginisiasi Rancangan Qanun (Raqan) Perlindungan Satwa. Karena ini merupakan inisiatif DPRA, maka DPRA harus menyiapkan draf dan 
memparipurnakan menjadi rancangan qanun inisiatif lembaga.

Pada Tahun 2018 ada 8 judul raqan inisiatif DPRA yang salah satunya adalah Raqan Perlindungan Satwa. Raqan Perlindungan Satwa menjadi rancangan qanun inisiatif lembaga, hingga akhirnya masuk dalam Prolega DPRA 2018 yang masuk dalam prioritas Program Legislasi (Prolega) Tahun 2018.

Pembahasan raqan perlindungan satwa tersebut pada Tahun 2018 mengalami proses panjang, hingga sempat tertunda. Berganti tahun, raqan itu kembali dimasukkan menjadi Raqan Inisiatif DPRA dalam Raqan Prolega 2019.

Dalam pembahasannya raqan perlindungan satwa ini termasuk yang paling aspiratif, karena proses pembuatan qanun ini sangat terbuka yaitu ditandai dengan keterlibatan publik yang sangat tinggi. Hampir semua NGO bidang lingkungan yang ada di Aceh dilibatkan, termasuk konsultasi dengan NGO nasional dan Internasional (Admin, 2019)

Berkenaan dengan penyusunan qanun mengenai perlindungan terhadap satwa liar, belum pernah ada sebelumnya yang mengangkat terkait isu ini untuk kemudian dituangkan dalam bentuk karya ilmiah yang berkaitan pengabdian kepada masyarakat. Hal ini disebabkan karena penyusunan qanun pengelolaan satwa liar di Aceh adalah yang pertama kalinya sebagai turunan dari UU Nomor 5 Tahun 1990 tentang Konservasi Sumber Daya Alam Hayati dan Ekosistemnya. Akan tetapi, sebagai referensi terdapat beberapa tulisan jurnal pengabdian yang terkait dengan isu penyusunan peraturan daerah, antara lain pengabdian yang dilakukan oleh Suwari Akhmaddhian dengan judul "Pelatihan Pembuatan Peraturan Desa di Kecamatan Banjaran, Majalengka" (Suwari Akhmaddhian, 2020), dan I Gusti Ayu Ketut Rachmi Handayani dengan judul "Pembentukan Peraturan Daerah Berbasis Lingkungan dalam Rangka Mewujudkan Praktik-praktik Good Goovernance di Daerah" (I Gusti Ayu Ketut Rachmi Handayani, 2013).

Sebagai bagian dari pengabdian kepada masyarakat, maka peran penulis dalam pengabdian kepada masyarakat ini adalah dengan turut serta membantu tim tenaga ahli dari Komisi II DPRA dalam proses penyusunan qanun satwa liar tersebut hingga akhirnya qanun ini disahkan pada 27 September 2019 dan kemudian diundangkan menjadi Qanun pada 29 Oktober 2019 lalu. 
2. METODE PELAKSANAAN

Metode pelaksanaan dalam pengabdian kepada masyarakat ini adalah dengan turut terlibat bersama tim tenaga ahli komisi II DPRA dalam menyusun Rancangan Qanun Pengelolaan Satwa Liar hingga akhirnya qanun ini disahkan dan diundangkan.

Turut sertanya penulis dalam penyusunan Rancangan Qanun Pengelolaan Satwa Liar ini adalah meliputi sebagian dari proses tahapan pembentukan qanun, antara lain mulai dari tahapan perencanaan, penyusunan, dan pembahasan. Sedangkan tahapan pengesahan atau penetapan, pengundangan, dan penyebarluasan dilakukan oleh DPRA dan Pemerintah Aceh sendiri sesuai dengan tugas, fungsi dan wewenangnya masing-masing.

\section{HASIL DAN PEMBAHASAN}

Berdasarkan ketentuan Pasal 1 angka 10 UU Pemerintahan Daerah sebagaimana yang telah dijelaskan di atas, Peraturan daerah adalah Peraturan Daerah Provinsi dan/atau peraturan daerah Kabupaten/kota. Peraturan Daerah dibuat oleh pemerintah setempat untuk melaksanakan peraturanperaturan lain yang lebih tinggi derajatnya (Bagir Manan, 2002:136).

Peraturan Daerah merupakan salah satu jenis Peraturan
Perundang-undangan dan merupakan bagian dari sistem hukum nasional yang berdasarkan Pancasila. Peraturan Daerah mempunyai kedudukan yang sangat strategis karena diberikan landasan konstitusional yang jelas sebagaimana diatur dalam Pasal 18 ayat (6) Undang-Undang Dasar Negara Republik Indonesia Tahun 1945 (Direktorat Jenderal Peraturan Perundang-Undangan Kementerian Hukum dan Hak Asasi Manusia RI, 2011).

Peraturan Daerah mempunyai berbagai fungsi yaitu (Direktorat Jenderal Peraturan PerundangUndangan Kementerian Hukum dan Hak Asasi Manusia RI, 2011):

a) sebagai instrumen kebijakan untuk melaksanakan otonomi daerah dan tugas pembantuan sebagaimana diamanatkan dalam Undang-Undang Dasar Negara Republik Indonesia Tahun 1945 dan Undang-Undang tentang Pemerintahan Daerah.

b) merupakan peraturan pelaksanaan dari Peraturan Perundang-undangan yang lebih tinggi. Dalam fungsi ini, Peraturan Daerah tunduk pada ketentuan hierarki Peraturan Perundang-undangan. Dengan demikian Peraturan Daerah tidak boleh bertentangan dengan Peraturan Perundang-undangan yang lebih tinggi. 
c) sebagai penampung kekhususan dan keragaman daerah serta penyalur aspirasi masyarakat di daerah, namun dalam pengaturannya tetap dalam koridor Negara kesatuan Republik indonesia yang berlandaskan Pancasila dan Undang-Undang Dasar Negara Republik indonesia Tahun 1945.

d) sebagai alat pembangunan dalam meningkatkan kesejahteraan daerah.

Di daerah Aceh, Peraturan Daerah disebut dengan Qanun. Pengertian Qanun sendiri dalam Kamus Besar Bahasa Indonesia (KBBI) dikenal dengan nama "Kanun", yang artinya adalah undang-undang, peraturan, kitab undang-undang, hukum dan kaidah (Pusat Pembinaan dan Pengembangan Bahasa Departemen Pendidikan dan Kebudayaan, n.d.:442). Adapun pengertian Qanun menurut kamus Bahasa Arab adalah undang-undang, kebiasaan atau adat (Mahmud Yunus, 1989:357). Jadi dapat disimpulkan bahwa pengertian dari Qanun adalah suatu peraturan perundangundangan atau aturan hukum yang berlaku di suatu daerah, dalam hal ini di Provinsi Aceh.

Berdasarkan Pasal 1 angka 1 Undang-Undang Nomor 12 Tahun 2011 tentang Pembentukan Peraturan Perundang-undangan, pembuatan Peraturan Perundangundangan antara lain mencakup tahapan perencanaan, penyusunan, pembahasan, pengesahan atau penetapan, pengundangan, dan penyebarluasan.

\section{Perencanaan}

Perencanaan

penyusunan

Peraturan Daerah dilakukan dalam Program Legislasi Daerah (Prolegda). Prolegda adalah instrumen perencanaan program pembentukan Peraturan Daerah Provinsi atau Peraturan Daerah Kabupaten/Kota yang disusun secara terencana, terpadu dan sistematis.

Perencanaan Peraturan Daerah Provinsi dilakukan dalam Prolegda Provinsi. Penyusunan Prolegda Provinsi dilaksanakan oleh DPRD Provinsi dan Pemerintah Daerah Provinsi. Prolegda Provinsi ditetapkan untuk jangka waktu 1 tahun berdasarkan skala prioritas pembentukan Rancangan Peraturan Daerah Provinsi. Penyusunan dan penetapan Prolegda Provinsi dilakukan setiap tahun sebelum penetapan Rancangan Peraturan Daerah Provinsi tentang APBD Provinsi.

\begin{tabular}{lrr}
\multicolumn{1}{c}{ Kriteria } & skala & prioritas \\
penyusunan & daftar & rancangan \\
peraturan daerah dalam & Prolegda \\
didasarkan & pada 1$)$ & perintah \\
Peraturan & Perundang-undangan
\end{tabular}


yang lebih tinggi; 2) rencana pembangunan daerah; 3) penyelenggaraan otonomi daerah dan tugas pembantuan; dan 4) aspirasi masyarakat daerah.

Dalam Prolegda dapat dimuat daftar kumulatif terbuka yang terdiri atas akibat putusan Mahkamah Agung dan Anggaran Pendapatan dan Belanja Daerah Provinsi. Serta dalam keadaan tertentu, DPRD atau Gubernur dapat mengajukan Rancangan Peraturan Daerah Provinsi di luar Prolegda Provinsi, yang terdiri atas 1) untuk mengatasi keadaan luar biasa, keadaan konflik, atau bencana alam; 2) akibat kerjasama dengan pihak lain; dan 3) keadaan tertentu lainnya yang memastikan adanya urgensi atas suatu Rancangan Peraturan Daerah Provinsi yang dapat disetujui bersama oleh alat kelengkapan DPRD Provinsi yang khusus menangani bidang legislasi dan biro hukum.

\section{Penyusunan}

Rancangan Peraturan Daerah Provinsi dapat berasal dari DPRD Provinsi atau Gubernur. Rancangan Peraturan Daerah Provinsi sebagaimana dimaksud disertai dengan penjelasan atau keterangan dan/atau Naskah Akademik. Dalam hal Rancangan Peraturan Daerah Provinsi mengenai anggaran pendapatan dan Belanja Daerah Provinsi, pencabutan Peraturan
Daerah Provinsi; atau Perubahan Peraturan Daerah Provinsi yang hanya sebatas mengubah beberapa materi, disertai dengan keterangan yang memuat pokok pikiran dan materi muatan yang diatur.

Naskah Akademik adalah naskah hasil penelitian atau pengkajian hukum dan hasil penelitian lainnya terhadap suatu masalah tertentu yang dapat dipertanggungjawabkan secara ilmiah mengenai pengaturan masalah tersebut dalam suatu Rancangan Undang-Undang, Rancangan Peraturan Daerah Provinsi, atau Rancangan Peraturan Daerah Kabupaten/Kota sebagai solusi terhadap permasalahan dan kebutuhan hukum masyarakat (Pasal 1 angka 11). Setiap Rancangan Peraturan Daerah (Provinsi/Kabupaten/Kota) harus disertai dengan Naskah Akademis (Pasal 33 ayat (3).

Pengharmonisasian, pembulatan, dan pemantapan konsepsi Rancangan Peraturan Daerah Provinsi yang berasal dari Gubernur dikoordinasikan oleh biro hukum dan dapat mengikutsertakan instansi vertikal dari kementerian yang menyelenggarakan urusan pemerintahan di bidang hukum, sedangkan yang berasal dari DPRD Provinsi dikoordinasikan oleh alat 
kelengkapan DPRD Provinsi yang khusus menangani bidang legislasi.

Ketentuan

mengenai

penyusunan Peraturan Daerah

Provinsi berlaku secara mutatis mutandis terhadap penyusunan Peraturan Daerah Kabupaten/Kota.

\section{Pembahasan}

Pembahasan

Rancangan

Peraturan Daerah di DPRD dilakukan oleh DPRD bersama Kepala Daerah. Pembahasan bersama tersebut dilakukan melalui tingkat-tingkat pembicaraan, yang dilakukan dalam rapat: komisi, panitia, alat kelengkapan DPRD yang khusus menangani bidang legislasi, dan paripurna. Ketentuan lebih lanjut mengenai tata cara pembahasan Ranperda diatur dengan Peraturan Dewan Perwakilan Rakyat Daerah.

Rancangan Peraturan Daerah dapat ditarik kembali sebelum dibahas bersama oleh DPRD dan Kepala Daerah. Sedangkan Rancangan Peraturan Daerah yang sedang dibahas hanya dapat ditarik kembali berdasarkan persetujuan bersama DPRD dan Kepala Daerah. Ketentuan mengenai tata cara penarikan kembali Rancangan Peraturan Daerah diatur dengan Peraturan DPRD.

\section{Pengesahan atau Penetapan}

Rancangan Peraturan Daerah yang telah disetujui bersama oleh
DPRD dan Kepala Daerah disampaikan oleh pimpinan DPRD kepada Kepala Daerah untuk ditetapkan menjadi Peraturan Daerah. Penyampaian Ranperda tersebut dilakukan paling lama 7 hari sejak tanggal persetujuan bersama. Ranperda tersebut ditetapkan oleh Kepala Daerah untuk menjadi Peraturan Daerah dengan membubuhkan tanda tangan dan dalam jangka waktu paling lama 30 hari sejak Ranperda disetujui bersama. Dalam jangka waktu 30 hari Kepala Daerah tidak menandatangani Ranperda yang sudah disetujui bersama, maka Ranperda tersebut sah menjadi Peraturan Daerah dan wajib diundangkan.

\section{Pengundangan}

Peraturan

Daerah

(Provinsi/Kabupaten/Kota)

diundangkan dalam Lembaran

Daerah (Provinsi/

Kabupaten/Kota). Peraturan Gubernur dan Peraturan Bupati/Walikota diundangkan dalam Berita Daerah (Provinsi/Kabupaten/Kota).

Pengundangan Peraturan Daerah dalam Lembaran Daerah dan Berita Daerah dilaksanakan oleh Sekretaris Daerah. Peraturan Perundang-undangan mulai berlaku dan mempunyai kekuatan mengikat pada tanggal diundangkan, kecuali ditentukan lain di dalam Peraturan 
Perundang-undangan yang bersangkutan.

\section{Penyebarluasan}

Penyebarluasan dilakukan oleh DPRD dan Pemerintah Daerah sejak penyusunan Prolegda, penyusunan Rancangan Peraturan Daerah, pembahasan Rancangan Peraturan Daerah, hingga Pengundangan Peraturan Daerah. Penyebarluasan dilakukan untuk dapat memberikan informasi dan/atau memperoleh masukan masyarakat dan para pemangku kepentingan. Penyebarluasan Prolegda dilakukan bersama oleh DPRD dan Pemerintah Daerah Provinsi atau Kabupaten/Kota yang dikoordinasikan oleh alat kelengkapan DPRD yang khusus menangani bidang legislasi.

Penyebarluasan Rancangan Peraturan Daerah yang berasal dari DPRD dilaksanakan oleh alat kelengkapan DPRD. Penyebarluasan Rancangan Peraturan Daerah yang berasal dari Gubernur atau Bupati/Walikota dilaksanakan oleh Sekretaris Daerah. Penyebarluasan Peraturan Daerah Provinsi atau Peraturan Daerah Kabupaten/Kota yang telah diundangkan dalam Lembaran Daerah dilakukan bersama oleh DPRD dan Pemerintah Daerah Provinsi atau Kabupaten/Kota.

Naskah Peraturan Perundangundangan yang disebarluaskan harus merupakan salinan naskah yang telah diundangkan dalam Lembaran Daerah, Tambahan Lembaran Daerah, dan Berita Daerah.

Secara nasional, perlindungan terhadap satwa liar diatur dalam Undang-Undang Nomor 5 Tahun 1990 tentang Konservasi Sumber Daya Alam Hayati dan Ekosistemnya. Oleh sebab itu dalam konteks daerah Aceh, untuk melaksanakan peraturan yang lebih tinggi derajatnya tersebut diperlukan adanya qanun yang mengatur mengenai perlindungan terhadap satwa liar. Adanya pembentukan qanun perlindungan satwa liar ini merupakan bentuk dari upaya serius Pemerintah Aceh dalam memberikan perlindungan terhadap satwa liar di Aceh, dalam hal untuk memastikan perlindungan habitat dan koridor satwa dari dampak pembangunan infrastruktur, serta penegakan hukum terhadap kejahatan satwa.

Ketua Komisi II DPRA, Nurzahri pada Jum'at 24 Mei 2019 dalam sidang paripurna saat membaca laporan Komisi II DPRA dalam Penyiapan Draf Rancangan Qanun Tentang Perlindungan Satwa Liar, menjelaskan alasan mengapa perlu adanya Qanun yang mengatur mengenai perlindungan Satwa. Dalam laporan tersebut dinyatakan bahwa konflik antara manusia dan 
satwa liar cenderung meningkat akhir-akhir ini di Aceh. Pada kondisi tertentu konflik tersebut dapat merugikan semua pihak yang berkonflik. Kerugian yang umum terjadi akibat konflik di antaranya seperti rusaknya tanaman pertanian dan/atau perkebunan serta pemangsaan ternak oleh satwa liar, atau bahkan menimbulkan korban jiwa manusia. Ia menjelaskan lagi, Rancangan Qanun tentang Perlindungan Satwa ini memuat norma hukum lingkungan hidup. Norma-norma tersebut dituangkan dalam rancangan qanun yang mengatur tentang tujuan dan sasaran perlindungan satwa liar, perlindungan satwa liar terpadu, kelembagaan dan koordinasi, koridor satwa liar, peran serta masyarakat, rehabilitasi dan relokasi satwa liar, serta larangan-larangan yang harus dipatuhi oleh semua pihak agar dapat menjamin kelestarian dan keberlanjutan satwa liar di bumi Aceh. Rancangan Qanun ini diharapkan menjadi landasan hukum bagi Pemerintah Aceh, Pemerintah kabupaten/kota dan pemangku kepentingan lainnya dalam melakukan perlindungan satwa liar di Aceh (Ketua Komisi II DPR Aceh, Nurzahri dalam Redaksi, 2019).

Selain itu, lahirnya qanun ini juga bergerak dari keresahan tingginya perburuan satwa dilindungi di Aceh selama ini. Seperti data dari Balai Konservasi Sumber Daya Alam (BKSDA) Aceh, konflik gajah dengan manusia selama 4 tahun terakhir mengalami naik turun. Terdapat 39 kali konflik terjadi antara gajah dengan manusia pada Tahun 2015, kemudian meningkat menjadi 46 kali pada Tahun 2016. Jumlah gajah tewas di Tahun 2015 adalah sebanyak 14 ekor. Konflik gajah dengan manusia terus terjadi peningkatan, pada Tahun 2017 menjadi tahun tertinggi konflik satwa, yaitu mencapai 103 kali. Sebanding dengan terjadi konflik, Tahun 2017 juga bisa disebutkan tahun yang tinggi gajah tewas yaitu mencapai 13 ekor. Lalu pada Tahun 2018 hanya ditemukan 11 ekor gajah tewas dengan berbagai macam penyebab. Gajah sumatera secara undang-undang menjadi satwa yang dilindungi dari 4 (empat) satwa kunci lainnya, yaitu Harimau Sumatera, Orangutan Sumatera dan Badak Sumatera. Keempat satwa kunci itu terancam punah di Aceh. Semakin tinggi konflik satwa dengan manusia, semakin tinggi pula kerentanan punahnya satwa langka tersebut. Gajah sumatera misalnya, saat ini di Aceh populasinya hanya kisaran 500 sampai dengan 600 ekor. Bila ini tidak diselamatkan, generasi kedepannya hanya bisa melihat foto tanpa mengetahui wujud aslinya 
seperti apa (Data BKSDA dalam Afif, 2019).

Sedangkan mengenai penemuan jerat atau perangkap satwa yang dilindungi di Aceh berdasarkan laporan Forum Konservasi Leuser (FKL) Tahun 2018 terdapat 613 kasus perburuan, 96 kasus temuan satwa mati, 38 kasus perburuan diturunkan, 843 jerat diamankan, serta 176 camp pemburu dimusnahkan. Adapun jenis satwa yang paling banyak ditemukan jeratnya adalah burung yaitu 140 jerat, rusa, kijang, kambing hutan yaitu 278 jerat, landak dan mamalia kecil yaitu 192 jerat, dan harimau, beruang yaitu 233 jerat. Secara umum kasus perburuan terjadi penurunan Tahun 2018, tetapi temuan jerat atau perangkap justru meningkat pada Tahun 2018 dibandingkan Tahun 2017. Jumlah kasus temuan perburuan Tahun 2017 sebanyak 729 kasus, turun dibandingkan Tahun 2018 hanya 613 kasus. Sedangkan jerat justru semakin banyak ditemukan Tahun 2018 yaitu mencapai 843 jerat dan Tahun 2017 hanya 814 jerat (Data BKSDA dalam Afif, 2019).

\section{Mengingat pentingnya} mengenai perlindungan satwa liar ini, sehingga perlu adanya Qanun sebagai payung hukum yang mengatur perlindungan satwa liar di Aceh. Dalam hal ini, penulis turut serta membantu Tim Tenaga Ahli Komisi II DPRA dalam hal menyusun Rancangan Qanun Perlindungan Satwa Liar yang kemudian diundangkan menjadi Qanun pada 29 Oktober 2019.

Peran penulis bersama tim tenaga ahli dalam pengabdian kepada masyarakat ini meliputi tahapan:

\section{Perencanaan}

Awalnya inisiatif untuk mewujudkan qanun perlindungan satwa liar ini sudah dimulai dari Tahun 2017. Adanya desakan dari rekan-rekan NGO yang bergerak di isu lingkungan terkait konflik satwa di Aceh karena banyaknya satwa liar yang mati dan masyarakat yang menjadi korban, bahkah ada masyarakat yang meninggal akibat konflik dengan satwa liar.

Atas desakan dari beberapa pihak, Komisi II DPRA pada 2017 menginisiasi Rancangan Qanun (Raqan) Perlindungan Satwa liar ini. Bahkan penyusunan draf awal raqan ini banyak mendapat masukan dari lembaga WWF Indonesia.

Akhirnya Raqan ini mulai diperjuangkan pada Tahun 2018 dan merupakan raqan inisatif DPRA. Karena ini merupakan inisiatif DPRA, maka DPRA harus menyiapkan draf dan memparipurnakan menjadi rancangan qanun inisiatif lembaga. 
Pada Tahun 2018 Raqan

Perlindangan Satwa pun menjadi rancangan qanun inisiatif lembaga, hingga akhirnya masuk dalam Prolega DPRA 2018.

Dalam rapat paripurna di Gedung Serbaguna DPRA, 17 Januari 2018, DPRA mengesahkan 17 judul Rancangan Qanun (Raqan) yang masuk prioritas Program Legislasi (Prolega) Tahun 2018. Dalam rapat tersebut, ada 8 judul raqan inisiatif DPRA yang salah satunya adalah Raqan Perlindungan Satwa.

Pembahasan Raqan ini pada Tahun 2018 mengalami proses panjang, hingga sempat tertunda. Berganti tahun, raqan itu kembali dimasukkan menjadi Raqan Inisiatif DPRA dalam Raqan Prolega 2019.

Dewan Perwakilan Rakyat Aceh (DPRA) kembali menggelar rapat Paripurna Tahun 2019 di Gedung Utama DPRA pada Jum'at siang, 24 Mei 2019 dengan agenda penetapan dua Rancangan Qanun Usul Inisiatif Anggota DPRA menjadi Rancangan Qanun Inisiatif DPRA, dan salah satunya adalah Rancangan Qanun Aceh tentang Perlindungan Satwa Liar yang pengusulnya berasal dari Komisi II DPRA.

Pihak pengusul melalui Nurzahri sebagai Ketua Komisi II DPRA pada saat itu menyampaikan dan menjelaskan bahwa qanun ini bertujuan agar hutan Aceh dapat lebih terlindungi serta penguatan regulasi agar konflik satwa liar dengan manusia dapat diminimalisir. Setelah mendengar penjelasan dari pihak pengusul raqan inisiatif DPRA, pimpinan DPRA mengetuk palu, sebagai tanda bahwa seluruh anggota DPRA sepakat menetapkan Rancangan Qanun Aceh Usul Inisiatif Anggota DPR Aceh menjadi Rancangan Qanun Aceh Inisiatif DPR Aceh.

Dalam pembahasannya raqan ini termasuk yang paling aspiratif dan proses pembuatan qanun ini sangat terbuka yang dibuktikan dengan keterlibatan publik sangat tinggi. Hampir semua NGO bidang lingkungan yang ada di Aceh dilibatkan, termasuk konsultasi dengan NGO nasional dan Internasional. Selain itu tim perumus qanun juga difasilitasi oleh WWF ke India untuk melihat pengelolaan satwa liar di sana yang bersinergi dengan kehidupan masyarakat.

\section{Penyusunan}

Qanun tentang Perlindungan Satwa Liar di Aceh ini merupakan Qanun inisiatif dari Komisi II DPRA. Memulai langkah itu, Komisi II melakukan rapat perdana terkait rencana pembentukan Qanun tersebut bersama Dinas Lingkungan Hidup dan Kehutanan (DLHK) Aceh dan Lembaga 
Swadaya Masyarakat (LSM) di Aceh seperti WALHI, LBH Banda Aceh, JKMA, Koalisi NGO HAM, WWF, FFI serta berbagai unsur lainnya, pada Rabu 18 April 2019 di ruang Banggar DPRA. Tahap penyusunan draf qanun perlindungan satwa liar ini telah melewati proses panjang. Sejak masuk ke dalam prolegda 2019, qanun ini telah resmi untuk didraf dan kemudian disahkan menjadi qanun.

Proses penyusunan raqan yang telah dilewati penulis dalam membantu tim tenaga ahli dari Komisi II DPRA antara lain 1) Rapat penyusunan raqan untuk harmonisasi peraturan terkait dan mendengarkan masukan dari pihak akademisi yaitu Bapak Mawardi dan Bapak Yanis, yang bertempat di kantor DLHK Aceh di Ruang Pinus Merkuri Gedung C pada 22 Juni 2019; 2) Rapat penyusunan raqan untuk disesuaikan dengan dengan masukan yang diberikan oleh Pemerintah Aceh pada 28 Juni 2019; 3) Rapat penyusunan raqan untuk disesuaikan dengan dengan masukan dari Pemerintah Aceh dan berbagai pihak terkait pada 1 Juli 2019 di kantor FFI Aceh; 4) Rapat penyusunan raqan perlindungan satwa liar bersama Komisi II DPRA dengan melibatkan berbagai pihak terkait antara lain dari instansi pemerintah dan rekan-rekan LSM pada 2 Juli 2019 di Ruang Rapat
DPRA; 5) Rapat penyusunan rancangan qanun perlindungan satwa liar dengan kembali menyesuaikan masukan dari Pemerintah Aceh pada 24 Juli 2019; dan 5)Rapat penyusunan sebelum Rapat Dengar Pendapat Umum (RDPU) bersama tim perumus di 3 in 1 Coffee pada 29 Agustus 2019.

\section{Pembahasan}

Pada tahap pembahasan, para tim perumus sebelumnya melakukan rapat pembahasan Rancangan Qanun Perlindungan Satwa Liar pada 15 Agustus 2019 di ruang rapat Kadis DLHK Aceh. Rapat pembahasan ini dipimpin langsung oleh Kadis DLHK Aceh yaitu Ir. Sahrial. Turut hadir dalam rapat tersebut antara lain Penasehat Khusus Gubernur Bidang Lingkungan Hidup dan Kehutanan yaitu Bhakti Siahaan, Badan Perencanaan dan Pembangunan Daerah (Bappeda) Aceh, UPT Balai Konservasi Sumber Daya Alam (BKSDA) Aceh, Balai Pengelolaan Daerah Aliran Sungai dan Hutan Lindug (BPDASHL) Aceh, Balai Pemantapan Kawasan Hutan $(\mathrm{BPKH})$ Aceh, Balai Pengelolaan Hutan Produksi (BPHP) Aceh, Flora and Fauna International (FFI) Program Aceh, Conservation Response Unit (CRU) Aceh, Sumatran Orangutan Conservation Programe - Yayasan Ekosistem Lestari (SOCP - YEL), Yayasan 
Hutan, Alam, dan Lingkungan Aceh (HAkA), dan anggota Tim perumus Raqan Perlindungan Satwa Liar.

Hasil dari pembahasan raqan perlindungan satwa liar yang telah dilakukan tersebut, kemudian tim perumus mengadakan lagi rapat penyusunan untuk kemudian disesuaikan kembali dengan masukan yang telah diperoleh dari hasil rapat.

Kemudian pada Jum'at malam tanggal 30 Agustus 2019 di Gedung Utama DPRA, Komisi II Dewan Perwakilan Rakyat Aceh (DPRA) menggelar Rapat Dengar Pendapat Umum (RDPU) tentang Rancangan Qanun Perlindungan Satwa Liar. Sebelum dimulai RDPU, Ketua Komisi II DPRA Nurzahri terlebih dahulu memperkenalkan kepada seluruh peserta yang hadir tentang Kaukus Pembangunan Berkelanjutan Aceh.

Kaukus ini merupakan sebuah wadah pertemuan berkala berbagai pemangku kepentingan dari berbagai sektor bersama anggota parlemen untuk membahas isu-isu penting yang berkaitan dengan agenda pembangunan berkelanjutan di Aceh. Adapun sejumlah isu yang dibahas seperti pengelolaan resiko bencana alam, pengelolaan sumber daya alam, kedaulatan dan ketahanan pangan, Rencana Pembangunan Jangka Menengah (RPJM) hijau, energi bersih- terbarukan serta isu pengelolaan sumber daya kelautan dan maritim dan juga isu lain yang berkembang. Kaukus ini kemudian disinkronkan dengan RDPU Rancangan Qanun Perlindungan Satwa Liar yang diinisiasi oleh Komisi II DPRA.

Dalam RDPU ini juga turut dihadiri oleh Pejabat Forum Koordinasi Pimpinan Daerah (Forkopimda) Aceh, Kepala Satua Kerja Pemerintah Aceh (SKPA), Perwakilan Peguruan Tinggi, LSM/NGO, Pengusaha, Tokoh Masyarakat dan pihak terkait lainnya, sehingga lebih memperkaya masukan yang diberikan dalam RDPU Raqan Perlindungan Satwa Liar ini.

$$
\text { Pada RDPU Raqan }
$$
perlindungan satwa liar ini juga dijelaskan mengenai substansi yang dituangkan dalam raqan sehingga semua pihak yang hadir dapat turut memberikan masukannya. Kemudian dijelaskan bahwa Raqan Perlindungan Satwa Liar ini terdiri 13 bab 20 pasal. Selain mengatur habitat dan jenis-jenis satwa dilindungi, dalam rancangan qanun tersebut juga mengatur pidana perburuan, perdagangan, maupun kejahatan terhadap satwa dilindungi berupa hukuman cambuk hingga 60 kali. Tentunya dalam RDPU ini banyak terdapat masukan yang positif dari berbagai pihak. 
Setelah dilakukannya RDPU, kemudian tim perumus melakukan konsultasi raqan ke Kementerian Dalam Negeri (Kemendagri) dan Kementerian Lingkungan Hidup dan Kehutanan (KemenLHK) pada 04 September 2019.

Dalam konsultasi tersebut, Kemendagri tidak setuju dengan penerapan hukuman cambuk untuk pelaku kejahatan satwa di Aceh. Menurut Direktur Jenderal Otonomi Daerah Kemendagri Akmal Malik Piliang, sanksi hukuman cambuk dalam konteks pidana terhadap satwa liar tidak tercantum di dalam Qanun Nomor 6 Tahun 2014 tentang Hukum Jinayat dimana hukum jinayat merupakan peraturan daerah yang mengatur pidana Islam, salah satunya penerapan hukuman cambuk.

Kemendagri merekomendasikan agar hukuman terhadap pelaku kejahatan terhadap satwa liar mengacu pada Undang-Undang
Nomor 5 Tahun 1990 tentang Konservasi Sumber Daya Alam.

Setelah konsultasi tersebut tim perumus mengadakan rapat kembali untuk menyesuaikan masukan yang diberikan oleh Kemendagri dan KemeLHK pada 12-13 September dan 23-24 September 2019.

Setelah proses penyusunan dan pembahasan telah dilalui semua, maka tahap selanjutnya yaitu pengesahan atau penetapan, pengundangan, dan penyebarluasan dilakukan oleh DPRA dan Pemerintah Aceh sesuai dengan tugas, fungsi, dan wewenangnya masing-masing. Pada tanggal 27 September 2019, akhirnya raqan ini telah disahkan dan kemudian diundangkan menjadi Qanun pada 29 Oktober 2019 dengan nama Qanun Pengelolaan Satwa Liar. Berikut disajikan gambar 1,2 dan 3 saat diadakan rapat penyusunan Raqan Komisi II DPRA.

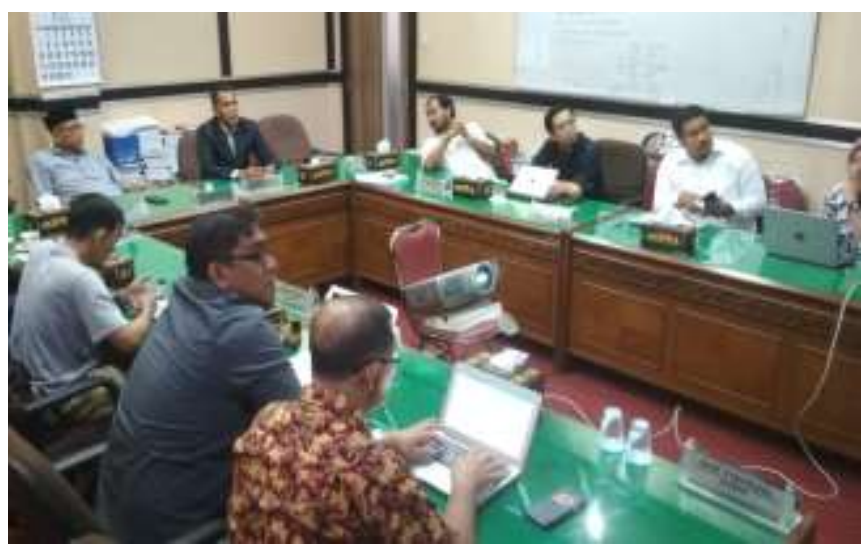

Gambar 1. Rapat Penyusunan Raqan Bersama Komisi II DPRA 


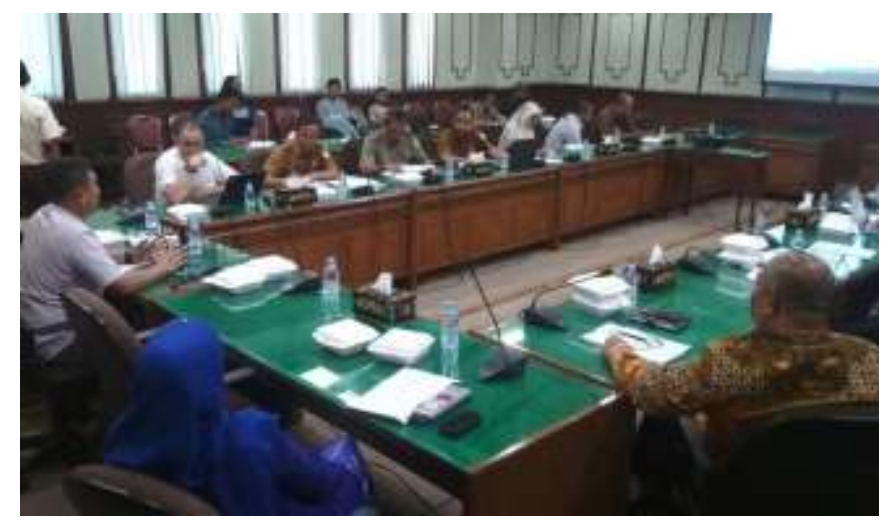

Gambar 2. Rapat Penyusunan Raqan di Ruang Rapat DPRA

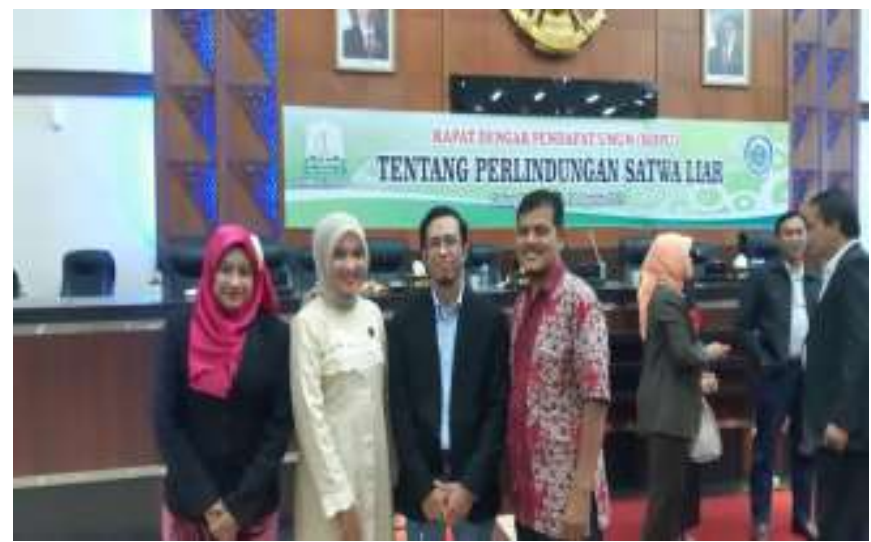

Gambar 3. Foto bersama setelah RDPU

\section{PENUTUP}

Konflik manusia dengan satwa liar merupakan permasalahan yang kompleks karena bukan hanya berhubungan dengan keselamatan manusia tetapi juga dengan keselamatan satwa liar itu sendiri. Berbagai konflik yang terjadi telah mendorong Pemerintah Aceh, Pemerintah Kabupaten/Kota dan para pihak terkait untuk lebih bijaksana dalam memahami kehidupan satwa liar sehingga tindakan penanganan dan pencegahannya dapat lebih optimal dan berdasarkan akar permasalahannya. Untuk itu, diperlukan sebuah payung hukum dalam bentuk qanun yang diharapkan mampu mengintegrasikan semua sumber daya yang dimiliki guna melakukan perlindungan terhadap satwa liar di Aceh.

Sebagai bentuk dari pengabdian kepada masyarakat, penulis juga turut terlibat bersama tim tenaga ahli komisi II DPRA dalam menyusun Rancangan Qanun Pengelolaan Satwa Liar hingga akhirnya qanun 
ini disahkan pada tanggal 27 September 2019 dan kemudian diundangkan menjadi Qanun pada 29 Oktober 2019 lalu.

Dalam penyusunan Rancangan Qanun Pengelolaan Satwa Liar ini peran penulis meliputi sebagian dari proses tahapan pembentukan qanun, antara lain mulai dari tahapan perencanaan, penyusunan, dan pembahasan. Sedangkan tahapan pengesahan atau penetapan, pengundangan, dan penyebarluasan dilakukan oleh DPRA dan Pemerintah Aceh sendiri sesuai dengan tugas, fungsi dan wewenangnya masing-masing.

\section{DAFTAR PUSTAKA}

ABC. (2019). Perlu Terobosan Hukum, Pemburu Liar Di Aceh Dihukum Cambuk. Retrieved from Tempo.co website: https://www.tempo.co/abc/47 96/perlu-terobosan-hukumpemburu-liar-di-aceh-dihukumcambuk

Admin. (2019). Bikin Qanun Perlindungan Satwa, DPRA Sempat Studi ke India. Retrieved from Dialeksis website:

https://dialeksis.com/Parlemen Kita/bikin-qanunperlindungan-satwa-dprasempat-studi-ke-india/

Afif. (2019). Pemburu Satwa Dilindungi di Aceh Bakal Diberi Tambahan Hukuman 100 Cambuk. Retrieved from merdeka.com website: https://www.merdeka.com/pe ristiwa/pemburu-satwa-

dilindungi-di-aceh-bakal-diberitambahan-hukuman-100cambuk.html

Bagir Manan. (2002). Menyongsong Fajar Otonomi Daerah. Yogyakarta: PSH FH UII.

Direktorat Jenderal Peraturan Perundang-Undangan

Kementerian Hukum dan Hak Asasi Manusia RI. (2011). Panduan Praktis Memahami Perancangan Peraturan Daerah. Retrieved from Direktorat Jenderal Peraturan PerundangUndangan website: http:/ / ditjenpp.kemenkumham. go.id/files/jurnal/panduanpenulisan-perda.pdf

I Gusti Ayu Ketut Rachmi Handayani. (2013). Pembentukan Peraturan Daerah Berbasis Lingkungan dalam Rangka Mewujudkan PraktikPraktik Good Governance di Daerah. Yustisia Jurnal Hukum, 2(1), 66-73.

Mahmud Yunus. (1989). Kamus ArabIndonesia. Jakarta: PT. Hidakarya Agung.

Pusat Pembinaan Dan Pengembangan Bahasa Departemen Pendidikan Dan Kebudayaan. (n.d.). Kamus Besar Bahasa Indonesia. Jakarta: Balai Pustaka.

Redaksi. (2019). Perlu Ada Qanun yang Mengatur Perlindungan Satwa di Aceh. Retrieved from mediaaceh.co website: https://mediaaceh.co/2019/05 / perlu-ada-qanun-yangmengatur-perlindungan-satwa- 
di-aceh/

Soekanto, S. (2007). Sosiologi Suatu

Pengantar, Cetakan Pertama.

Jakarta: Raja Grafindo Persada.

Suwari Akhmaddhian. (2020).

Pelatihan Pembuatan Peraturan

Desa di Kecamatan Banjaran,

Majalengka. Empowerment:

Jurnal Pengabdian Masyarakat, e-

ISSN 2598-2052, 03(01), 6-13. 